\title{
Sorg og sykmelding
}

Ved Kari Wille Rekdal og Henning Herrestad

\section{Innledning}

Å miste noen i dødsfall er en del av selve livet; noe vi alle må regne med å oppleve. Noen ganger er det kun vemodig, som når en gammel tante på 95 år sovner stille inn etter et langt og rikt liv. Andre ganger skaper dødsfallet sterke sorgreaksjoner. En tenåringsjente kommer ikke hjem en lørdagskveld og blir funnet død en måned senere; et foreldrepar finner babyen sin død i barnesengen; et annet foreldrepar finner tenåringssønnen hengt i garasjen; en familiefar blir drept i en trafikkulykke. I slike situasjoner er det helt normalt å oppleve måneder og kanskje år med uro, søvnforstyrrelser, tretthet, konsentrasjonsvansker, hukommelsesvansker og sterke emosjonelle utbrudd med gråt og mange følelser.

For mange blir dette en livskrise, en opplevelse av at livet slik de har kjent det, rakner for dem. Situasjonen opptar dem hvert minutt de er våkne. I en slik situasjon er det mange som finner det vanskelig å utføre sitt arbeid som normalt. Denne kronikken tar for seg hvilke følger dette kan få for dem. Vi beskriver hvilke muligheter som finnes for å få sykmelding etter dagens regelverk. Kort sagt innebærer det en medikalisering av sorgen at man må få en sykmelding av en lege, og at legen da omgår at normal sorg ikke gir krav på sykepenger, med å finne en annen passende medisinsk diagnose. Arbeidet med å få en ny diagnose for komplisert sorg er etter vårt syn ikke en løsning på problemene med dagens regler. Vårt ønske et at man innfører en ny ordning med sorgpenger. Vi beskriver også alternativer som vil gi adgang til sykmelding for sørgende.

Problemstillingen at det ikke finnes hjemmel for å sykmelde mennesker i sorg, ble satt på spissen i tiden etter 22. juli 2011. Fastleger opplevde at de hadde valget mellom å sykmelde etterlatte for lidelser de ikke hadde, eller ikke å kunne sykmelde. Vi har også støtt på denne problematikken en rekke ganger både $\mathrm{i}$ samtale med sørgende som snakker om sine erfaringer hos fastlegen og i samtale med fastleger som forteller om sine erfaringer med å møte mennesker i sorg. Landsforeningen for uventet barnedød (LUB) har, sammen med foreningen $\mathrm{Vi}$ som har ett barn for lite og LEVE, i tiden etter dette gått sammen for å forsøke å få til en endring slik at også sorgrammede skal ha mulighet til å få sykmelding når det er nødvendig. Som et ledd i dette arbeidet har LUB foretatt en undersøkelse (Christoffersen og Johannessen 2013). Inklusjonskriteriene var at de etterlatte var $\mathrm{i}$ arbeid da de mistet barn eller andre nære personer, og at tapet skjedde for mindre enn 10 år siden. 395 responderte på invitasjonen til å delta som ble sendt medlemmene av de tre foreningene og spredd via foreningenes nettfora. Unders $\emptyset$ kelsen viser stor variasjon i behovet for sykefravær etter et dødsfall, men kun 6,3 \% returnerte etter mindre enn 2 uker. 35,2 \% fikk diagnosen psykisk ubalanse situasjonsbetinget, 20,1\% diagnosen depresjonsfølelse og 22,6\% visste ikke hvilken diagnose de hadde fått. 5 \% oppga at deres sykmeldingshistorie hadde hindret dem i å få en jobb de søkte på, og $12 \%$ at de hadde hatt problemer med å tegne forsikring. Kommentarene viste også at flere slet med negative følelser knyttet til å bære diagnosene de hadde fått.

\section{Velferdspermisjon}

I arbeidsmiljøloven og folketrygdloven finnes det bestemmelser om ulike former for stønad/fri/redusert arbeidstid i visse situasjoner. I avtaleverket mellom arbeidsgivere og arbeidstakerorganisasjoner gis det mulighet for velferdspermisjon med lønn ved dødsfall i nær familie. Arbeidsgiver har da plikt til å gi den ansatte fri med lønn. For kommuneansatte er dette begrenset til tre dager, mens statsansatte har avtaler om at velferdspermisjon kan gis inntil tolv arbeidsdager. I private virksomheter vil det variere alt ettersom hva som er avtalt eller praksis i virksomheten, men bare én dags velferdspermisjon er det vanlige. Dette er ment for å gi rom til å forberede og gjennomføre begravelsen. De første par ukene etter et dødsfall er for en del mennesker også en tid hvor de får mange henvendelser og besøk av venner og familie, og hvor de har mye praktisk å ordne opp i. Mange vil således ha brukt opp sine rettigheter allerede på begravelsestidspunktet. Men ofte er ikke de sterke sorgreaksjonene begynt å komme ennå, så tidlig etter dødsfallet. Mange forteller hvordan de opptrådte med fatning i begravelsen, og var for opptatt til å sørge mens alt dette stod på. Det er når stillheten senker seg etter begravelsen at reaksjonene øker i styrke. Velferdspermisjon er ikke egnet til å løse de problemene som da oppstår, og knapt nok tilstrekkelig til å få gjennomført begravelsen og alt praktisk som skal ordnes i tilknytning til en slik seremoni. De fleste arbeidsgivere, både statlige, kommunale og private, vil nok i mange tilfeller være åpne for å gi permisjon uten lønn, men det kan bare bli en kortsiktig løsning for de sørgende. Et alternativ til ordningen vi foreslår med sorgpenger etter folketrygdloven, kan være at arbeidsgivere utvider mulighetene for Iønnet velferdspermisjon i visse tilfeller. Da slipper man sykmeldingsproblematikken, men ulempen er at den ansatte kan føle seg overlatt til arbeidsgivers vurdering og velvilje.

\section{Dagens regler om sykmelding}

Når velferdspermisjon ikke dekker behovet for fri/redusert arbeidstid eller arbeidsoppgaver for et menneske i dyp sorg, er det sykmelding som står igjen som eneste alternativ hvis man ikke skal lide økonomisk. Sørgende som får problemer med å utføre sitt arbeid, oppsøker som regel fastlegen sin for å be om sykmelding. Men hvor godt tilpasset er gjeldende regler for sykmelding til denne gruppens behov? Når en lege skal sykmelde, skal hun vurdere flere aspekter knyttet til både pasientens person og vedkommendes arbeid. 


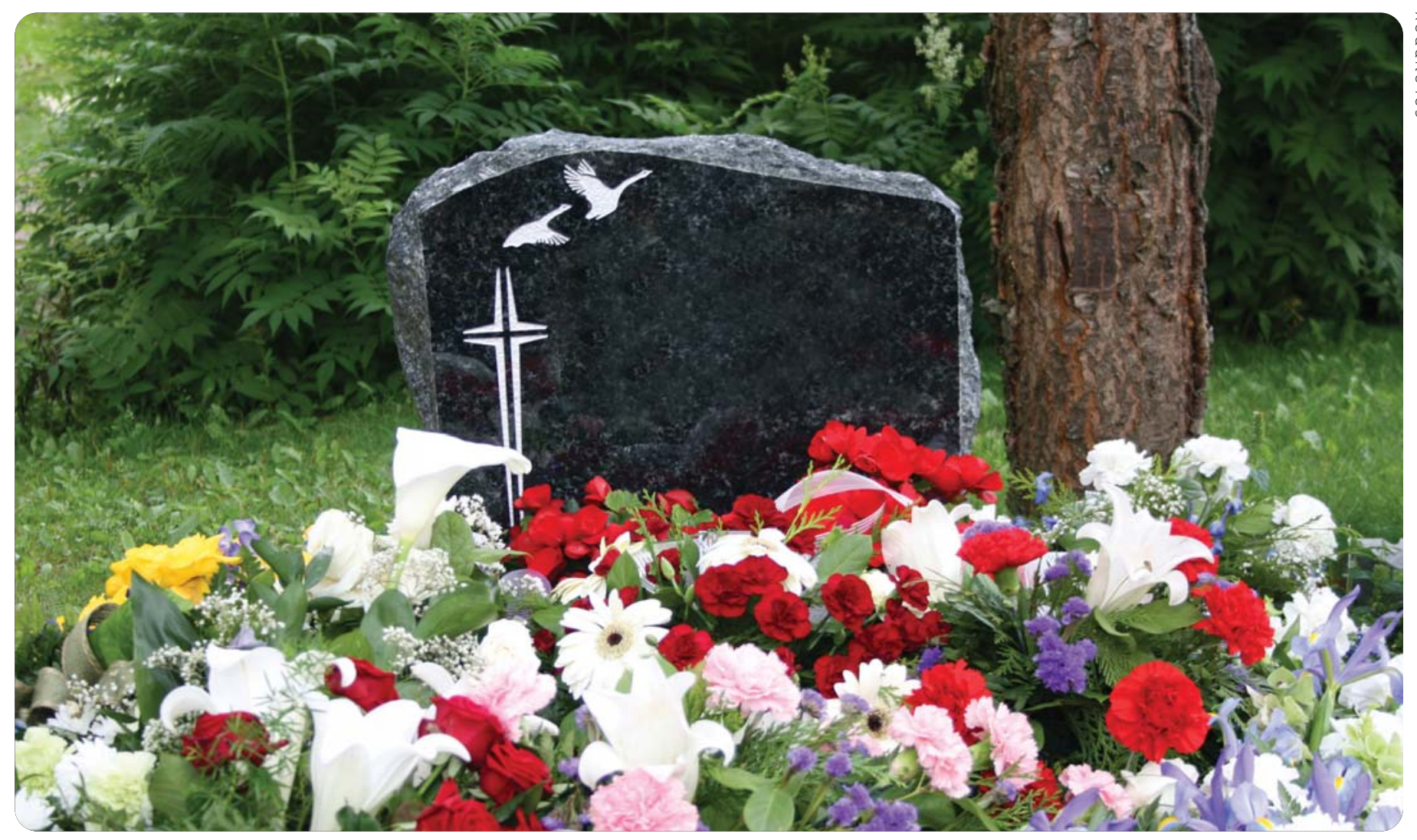

Her er spørsmålene legen må stille seg ifølge Helsedirektoratets veileder for sykmeldere: Er arbeidsevnen redusert på grunn av sykdom? Er det riktig å sykmelde her? Finnes det en alternativ løsning? Hva er mulig på pasientens arbeidsplass? Er disse vurderingene dekkende for et menneske med en alvorlig sorgreaksjon? Også NAVs håndbok for sykmelding (NAV, 2011) gir klare føringer for hvordan legen skal håndtere dette. Det står:

Det kan bare utstedes sykmeldingsattest dersom pasientens arbeidsuførhet skyldes en sykdom eller skade. Eksempler på tilstander som ikke defineres som sykdom, men som likevel kan nedsette arbeidsevne, er tretthet, normale sorgreaksjoner, nedstemthet, arbeidskonflikt eller lignende.

Slike tilstander gir i seg selv ikke rett til sykepenger, men kan utvikle seg på en slik måte at det medfører arbeidsuførhet. (NAV, 2011, s. 10, vår utheving.)

Det sies med andre ord i klartekst at normale sorgreaksjoner, slik vi har beskrevet dem over, ikke gir rett til sykepenger selv om de nedsetter arbeidsevnen helt eller delvis. Legen må konkludere at arbeidsuførheten skyldes en sykdomstilstand for å kunne utstede sykmelding. Videre står det:

Det skal alltid oppgis diagnose med kode. Kodesystemene som benyttes er:

- ICPC-2 (International Classification of Primary Care)

- ICD-10 (International Classification of Diseases)

ICPC er et system som primaert er laget for å ivareta konsultasjonsårsaken.

Det er derfor ikke alle diagnoser som gir grunnlag for sykmelding (eksempel Z Sosiale problemer). Leger i primarhelsetjenesten forutsettes å bruke ICPC. Sykehusleger og praktiserende spesialister kan velge mellom ICPC og ICD. (NAV, 2011, s 11.)

De såkalte Z-kodene i ICPC-2 har følgende koder: Z15 Problem dødsfall/tap av partner og Z19 Problemdødsfall/tap av barn og Z23 Problem dødsfall/tap av foreldre/ familie. Det framgår likevel av sitatet over at disse funksjonsdiagnosene ikke gir grunnlag for sykmelding. Legen må finne grunnlag for å stille en sykdomsdiagnose.

De fleste fastlegene benytter som oftest P02 Psykisk ubalanse situasjonsbetinget, P03 Depresjonsfølelse eller P29 Psykiske symptomer/plager IKA INA (dvs. Ikke Klassifisert Annet sted eller lkke Nærmere Angitt). Noen ganger benyttes også A29 Generelle symptomer/plager IKA eller INA. Helsedirektoratets sykmelderveileder foreslår at den sørgende i stedet for sykmelding kan vurdere ferie og avspasering, egenmelding, og spørre arbeidsgiver om utvidet permisjon med lønn. Alle disse forslagene har det til felles at de vil være av kortere varighet, og at den sørgende risikerer å få utbetalt mindre i lønn i perioder. I tillegg krever de at den sørgende selv tar initiativ, noe mange kanskje ikke vil klare i den tilstanden de for øyeblikket befinner seg $\mathrm{i}$. 


\section{Om sorg og depresjon}

Slik depresjonsdiagnosene er utformet i diagnosemanualene, vil alle som sliter med alvorlige sorgreaksjoner ha nok symptomer på depresjon til å oppfylle minst én av de ulike depresjonsdiagnosene. $0 \mathrm{~m}$ legen kun legger diagnosekriteriene til grunn, vil legen dermed kunne konkludere at den sørgende også lider av en depresjon og dermed har rett til sykmelding.

Hvis legen derimot bruker sitt kliniske skjønn, er det ikke vanskelig å skille mellom normal sorg og depresjon. Vi har ikke plass til en full drøfting av skillene, men gjengir her en skjematisk framstilling av professor Katherine Shear som vi har oversatt:

\begin{tabular}{|l|l}
\hline Depresjon & \multicolumn{1}{c}{ Sorg } \\
\hline $\begin{array}{l}\text { Tap av inte- } \\
\text { resse og glede }\end{array}$ & $\begin{array}{l}\text { Sterk interesse } \\
\text { i avdøde }\end{array}$ \\
\hline $\begin{array}{l}\text { Nedstemthet } \\
\text { uavhengig av } \\
\text { situasjon }\end{array}$ & $\begin{array}{l}\text { Utbrudd av sorg } \\
\text { utløses av } \\
\text { påminnelser om } \\
\text { den døde }\end{array}$ \\
\hline $\begin{array}{l}\text { Generelt lav } \\
\text { selvfølelse, } \\
\text { skyld og skam }\end{array}$ & $\begin{array}{l}\text { Skyld iforhold } \\
\text { til avdøde }\end{array}$ \\
\hline $\begin{array}{l}\text { Tilbake- } \\
\text { trekning }\end{array}$ & $\begin{array}{l}\text { Unngåelse av } \\
\text { påminnelser } \\
\text { om avdøde }\end{array}$ \\
\hline $\begin{array}{l}\text { Inǵen } \\
\text { påtrengende } \\
\text { minner }\end{array}$ & $\begin{array}{l}\text { gende minner } \\
\text { fra dødsfallet }\end{array}$ \\
\hline $\begin{array}{l}\text { Ingen lengsel } \\
\text { Stor lengsel } \\
\text { etter avdøde }\end{array}$ \\
\hline
\end{tabular}

Det er med andre ord en form for feildiagnostisering å gi en depresjonsdiagnose til mennesker med normale sorgreaksjoner. For at en person skal kunne sies å ha fått en depresjon midt i sorgen, må personen ha utviklet kjennetegnene i den venstre kolonnen.
Det kan selvsagt også skje at mennesker i sorg utvikler en depresjonslidelse eller har en slik lidelse som forverres av sorgen. Vi er enige i at disse bør få en depresjonsdiagnose og behandling for sin depresjon. Det vi reagerer på er bruken av depresjonsdiagnoser for å gi mennesker i normal sorg den sykmeldingen de ber om.

Det er flere uheldige følger av å feildiagnostisere normal sorg som depresjon. For det første kan det være at legen iverksetter en feilaktig behandling, f.eks. forordning av antidepressive medikamenter. For det andre vil depresjonsdiagnosen følge pasientens journal. Flere har erfart at de ved kjøp av livsforsikring må oppgi at de har en depresjonsdiagnose i sin journal, og at forsikringspremien da blir høyere. Psykiatriske diagnoser kan også gjøre det vanskelig å få den nødvendige sikkerhetsklarering som kreves for enkelte stillinger. For det tredje fører det til en skjev statistikk der tallet på pasienter med depressive lidelser blir høyere enn det egentlig er grunnlag for. For å kunne disponere midler og ressurser riktig innenfor helsefeltet er det av stor betydning med korrekte helsestatistikker. I tillegg vil det å gi feil diagnoser gi et galt bilde av de reelle årsakene til fravær.

\section{Om bruken av diagnosene P02, P29 og A29}

Vi har hørt flere leger anbefale at pasienter i sorg får diagnosene P02 Psykisk ubalanse situasjonsbetinget fordi dette er gunstigere for pasienten enn depresjonsdiagnoser. Leger vi har kontaktet i forbindelse med skrivingen av denne kronikken har også nevnt diagnosene P29 Psykiske symptomer/plager IKA INA og A29 Generelle symptomer/plager IKA eller INA. Det kan godt være at legene har rett $\mathrm{i}$ at disse diagnosene ikke vil være til ulempe for pasienten på et senere tidspunkt, og derfor er å foretrekke. Men det ligger en form for uredelighet i premissene for denne konklusjonen. For premissene er at legen vil finne en sykdomsdiagnose som gir rett til sykmelding for en pasient som har en normal sorg.
Mens NAV eksplisitt sier at normal sorg ikke gir rett til sykmelding. Fordi pasienter i mange ulike belastende livssituasjoner som gir funksjonsnedsettelser, men ikke sykdom, får disse diagnosene, hefter det også en slags mistanke ved dem. De er diagnoser legene bruker for å omgå et stivbent system.

Rapporten fra brukerundersøkelsen til LUB/LEVE/BFL (Christoffersen og Johannessen 2013) viser at etterlatte forteller om ubehag ved å få en psykisk diagnose når sorg er en naturlig reaksjon på en unaturlig hendelse. Det er særlig depresjonsdiagnosen mange reagerer på, og rapporten viser at det oppfattes som stigmatiserende å få både denne og andre feilaktige diagnoser. Det skyldes ikke at det er stigmatiserende å ha psykiske lidelser, men det oppleves ubehagelig å få en diagnose på en lidelse man ikke mener at man har. Mange vet faktisk ikke hvilken diagnose de har fått, og oppdager det først senere.

\section{Konsekvensene av at pasi-} enten ikke får sykmelding

Om legen følger NAVs retningslinjer for sykmelding, kan ikke legen skrive ut sykmelding til pasienter med normale sorgreaksjoner, selv om pasienten er helt arbeidsufør på grunn av disse reaksjonene. Det er sannsynlig at dette sjelden skjer, for den mest umiddelbare konsekvens er da gjerne at pasienten skifter til en fastlege som er villig til å omgå regelverket. Men det er ikke bare pasienten som finner en slik situasjon vanskelig og ubehagelig, også flere fastleger har offentlig gått ut med dette problemet.

Dersom fastlegene stod samlet $\mathrm{i}$ å håndheve NAVs regelverk, ville pasientene bli rammet i og med at arbeidsuførheten for mange er helt reell. De det gjelder, opplever at søvnmangel, tretthet, mangel på konsentrasjon og hukommelse gjør det umulig for dem å arbeide. Da er det en risiko for at sørgende føler seg tvunget til å ta permisjon uten lønn, gå ned i stillingsbrøk med tilsvarende redusert lønn eller i verste fall at de blir nødt til å slutte i jobben. 
Det er urimelig at arbeidstaker må ta hele belastningen selv gjennom redusert arbeid eller permisjon uten Iønn.

NAV ønsker at arbeidsgiverne skal ta belastningen med å tilrettelegge arbeidet slik at sørgende kan fortsette å arbeide selv om de er delvis arbeidsuføre. Mange arbeidsplasser er flinke til å gjøre dette. Vi har snakket med flere som har fortalt hvordan de har stått i arbeid selv om de ikke har produsert stort de månedene sorgreaksjonene var sterkest. De har vært glade for at dette var mulig. Hvorvidt det er mulig for arbeidsgiver å gjøre slike tilpasninger, vil variere avhengig av hva slags virksomhet det er og hva slags arbeidsoppgaver arbeidstakeren har.

Dersom en sørgende tvinges til å stå i arbeid fordi vedkommende ikke får sykmelding, og det ikke er mulig å tilrettelegge arbeidet, tror vi at den sørgende står i fare for å utvikle sykdomstilstander og i fare for å få forlenget tiden med akutte sorgreaksjoner. Vi mangler forskningsmessig dokumentasjon for dette, men sørgende etterlatte vil i hvert fall oppleve en redusert livskvalitet om de er tvunget til å hangle videre.

\section{Er det nå bra å gå hjemme med sorgen?}

Her er det ikke noe entydig svar som vil gjelde for alle. Mange sørgende vi har møtt som er i arbeid, sier at de er glade for at de må konsentrere seg om noe annet enn sorgen deler av dagen. For de fleste er arbeid en viktig del av livet, og deltagelse $\mathrm{i}$ arbeidslivet handler om identitet, å være av betydning og å oppleve mestring. Vi tror at det er best for mennesker å stå i arbeid om de har mulighet til det. Men vi er imot å tvinge mennesker som opplever seg arbeidsuføre, til å stå i arbeid bare fordi det er "normale sorgreaksjoner". Vi mener dette viser en manglende forståelse for hvor belastende normale sorgreaksjoner faktisk er for mange mennesker.

Det er et ønskemål fra samfunnet at så mange som mulig i arbeidsdyktig alder er i arbeid.

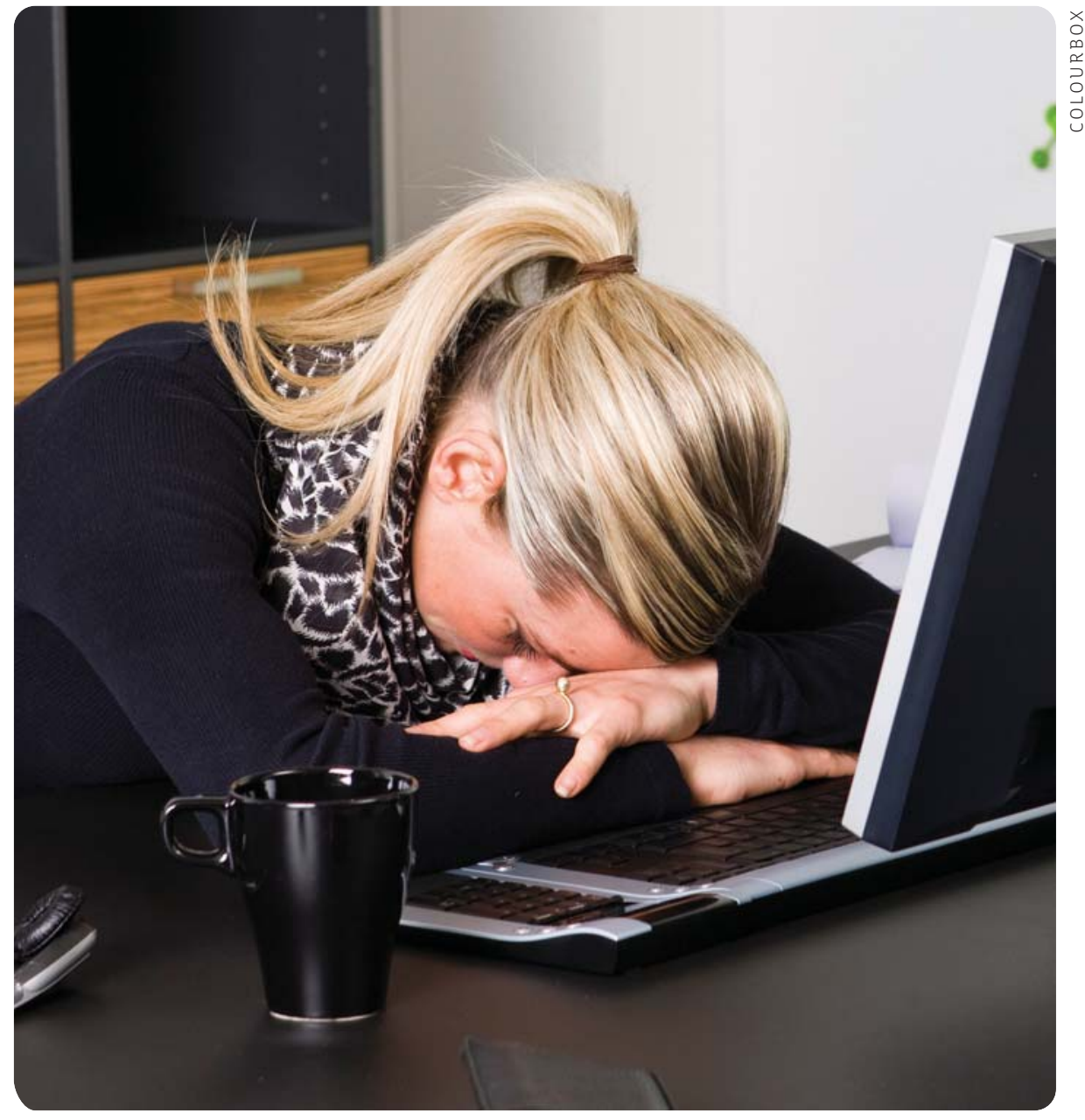

Høy arbeidsdeltakelse er ønskelig fra både individ- og samfunnsperspektiv. En fare ved langvarige sykmeldinger er at arbeidstaker faktisk faller ut av arbeidslivet og ender på uføretrygd. NAV er derfor svært opptatt av at arbeidstakere skal komme tilbake i arbeid så fort som mulig. NAV er pålagt å prioritere sykmeldingsoppfølging, men i praksis skjer det antakelig ikke så mye før på åtteukerstidspunktet. Før dette er det arbeidsgiver som har forpliktelsene og skal arrangere dialogmøte (med sykmeldende lege til stede) og lage en oppfølgingsplan. NAV vil nok ha forståelse for at det kan være behov for en kortvarig sykmelding av noen ukers varighet, men dersom åtteukerstidspunktet rundes, er det nok mange sykmeldte og deres arbeidsgivere som vil oppleve et påtrykk, i alle fall for å komme i gang i en gradert sykmelding.
Frykten for økning i antallet sykmeldte/trygdede

Norske politikere er redde for at om de gjør det lettere å få sykmelding eller trygd, vil vi få store mengder mennesker som velger trygd framfor arbeidsinntekt. Vi mener det er de reelle behovene for lettelser, snarere enn rigide oppfatninger om unnasluntring, som bør styre hva slags ordninger vi skal ha. I dag har vi et hyklersk system der behovene skjules. Mengden mennesker som får lettelser vil ikke nødvendigvis øke med de ordninger vi foreslår. Man vil bare kalle en spade for en spade, framfor å gi mennesker medisinske diagnoser de ikke har, for å gi dem rett til sykepenger de egentlig ikke har krav på. 


\section{En ny diagnose for komplisert sorg}

Det har gjennom mange år blitt publisert forskning som viser at noen mennesker sliter med hele spekteret av sterke sorgreaksjoner i årevis (Zisook \&t Shear, 2009). Man har funnet at dette ikke nødvendigvis innebærer at de har utviklet andre kjente psykiske lidelser som depresjon, angstlidelser eller posttraumatisk stressyndrom (PTSD). Flere studier viser at 7-10 \% av mennesker som har mistet noen i dødsfall utvikler en slik komplisert sorg (Kristensen, 2013). En forklaring på dette kan være at prosessen med å integrere sorgen er blitt blokkert på en eller annen måte.

I forbindelse med revisjonen av den amerikanske diagnosemanualen DSM ble det fremmet forslag om å gjøre komplisert sorg til en ny diagnose. Men det var mye uenighet om kriteriene, blant annet om hvor lang tid det må gå før man kan fastslå at integreringsprosessen er blokkert. Resultatet ble dermed at forslaget endte i et appendiks med forslag til diagnoser for en senere revisjon når ytterligere forskning har avklart kriteriene. I prosessen med å revidere ICD-10-manualen arbeider en gruppe for at komplisert sorg skal inkluderes. I og med at det er denne manualen som brukes i Norge, vil i så fall denne diagnosen kunne gi grunnlag for sykmelding når denne manualen tas i bruk. Den er varslet utgitt i 2015.

For de aller fleste mennesker i sorg vil dette ikke ha noen betydning. De sterke sorgreaksjonene melder seg gjerne i løpet av dager eller uker, noen ganger etter noen måneder, men diagnosen komplisert sorg kan ikke stiller før etter 6 måneder for barn og unge og etter 12 måneder for voksne om ICD-manualen følger DSMforslaget. Når diagnosen endelig kan stilles, vil mennesker med vanlige sorgreaksjoner ikke ha behov for sykmelding lenger.

\section{Våre ønsker om en endret rettstilstand}

Gjennom denne kronikken har vi forsøkt å synliggjøre at noen typer dødsfall er særlig belastende for de etterlatte og påfører dem ekstra belastninger som kan gi arbeidsuførhet på linje med sykdommer.
Vi har lagt vekt på å skille mellom disse situasjonene og den sorgen som er en normal del av livet, og likeledes mellom depresjon og sorgreaksjoner. Vi mener samfunnet bør ha respekt og forståelse for at normale sorgreaksjoner kan gi så stor grad av arbeidsuførhet i en periode at den sørgende må få permisjon fra arbeid. I bondesamfunnet ble en slik respekt vist gjennom at bygda hjalp de sørgende med å holde hjulene i gang. I vårt samfunn har vi ordningen med sykepenger fra NAV betalt av staten når sykdom eller skade gir arbeidsuførhet. Vi mener denne ordningen også må gjelde ved normale sorgreaksjoner. Den enkleste måten å gjennomføre dette på ville være å anerkjenne at Z-kodene Z15 Problem dødsfall/tap av partner og Z19 Problem dødsfall/tap av barn og Z23 Problem dødsfall/tap av foreldre/familie skal gi rett til sykmelding. Vår mening er at de samme former for sykmeldingsoppfølging skal gjelde hva enten man er sykmeldt ut fra Z-diagnosene eller man innfører en ordning med sorgpenger.

Sorg er bare én av mange situasjoner der mennesker er ute av stand til å stå i arbeid uten at dette skyldes sykdom eller skade. Vårt samfunn har de siste tiårene anerkjent tre slike situasjoner som støtteverdige. Friske gravide som har et arbeid som jordmor/lege mener kan gi risiko for skade på fosteret, og det ikke er mulig for tilrettelegging eller omplassering på arbeidsplassen, kan få svangerskapspenger. Foreldre til syke barn under 12 år kan få omsorgspenger. Man kan også få pleiepenger i inntil 60 dager om en nærstående er i livets sluttfase. Vi mener situasjonen med arbeidsuførhet som følge av naturlig sorg må anerkjennes som støtteverdig, og at man derfor som alternativ til sykmelding bør innføre en ordning med sorgpenger.

Oppfølging med formål om å få folk tilbake i arbeid bør være like tett når årsaken til sykmeldingen er sorg. Med andre ord ønsker vi at enten fastlegen eller NAV gjør en funksjonsvurdering av den sørgende, og kan innvilge fritak for arbeid og støtte dersom arbeidsfunksjonen er tilstrekkelig nedsatt.
Som ved sykmeldinger mener vi slike sorgpenger skal gis for en begrenset periode, og at man så gjør nye vurderinger av arbeidsevnen for å avgjøre om perioden eventuelt skal forlenges. Akkurat hvor grensen skal gå for hvor nedsatt arbeidsfunksjonen må være for å innvilge sorgpenger, må avklares nærmere. Man kan tenke seg faste grenser ut fra grad av søvnløshet, konsentrasjons- og hukommelsesvansker, eller at det beror på skjønn ut fra pasientens arbeidssituasjon.

\section{Takk til}

Forfatterne vil gjerne få takke Trine Giving Kalstad, fagsjef $i$ Landsforeningen uventet barnedød, og Rune Stenslet, lege og medisinsk kyndig rettsmedlem i Trygderetten, for viktige innspill til kronikken.

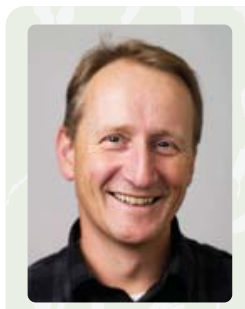

Henning Herrestad er arbeidende styreleder for LEVE - Landsforeningen for etterlatte ved selvmord. Han arbeider også som spesialrådgiver med ansvar for selvmordsforebygging ved Regionalt resssurssenter om vold, traumatisk stress og selvmordsforebygging (RVTS Øst). Han er utdannet dr.philos. i filosofi og gestaltterapeut MNGF.

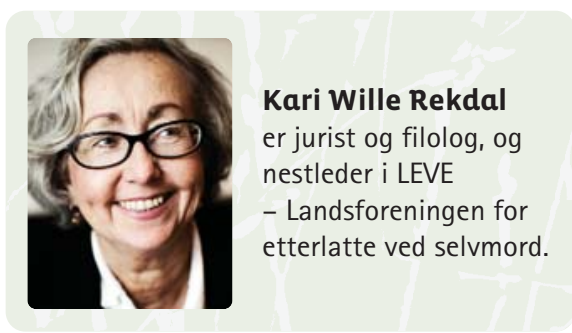

\section{Referanser}

Christoffersen, Line og Johannessen, Asbjørn (2013). Sorg og sykmelding. Etterlattes erfaringer med sykmelding etter brå død. Prosjektrapport for Landsforeningen uventet barnedød.

Kristensen, Pål (2013). Sorg som diagnose. Tidsskrift for den norske legeforening, vol 133, nr 8: 856-858. NAV (2011). Sykmelding - En håndbok i hvordan sykmelde. https://www.nav.no/Arbeid/Jobb+og +helse/ Sykmelding+og+sykepenger

Statens personalhåndbok, http://www.sph.dep.no/ Statens-Personalhandbok/

Veileder for sykmeldere. http://sykmelderveileder. helsedirektoratet.no/Sider/default.aspx

Zisook, Sidney og Shear, Katherine (2009). Grief and bereavement: what psychiatrists need to know. World Psychiatry, vol. 8:67-74. 